\title{
PRINCIPLES OF ORGANIZATION AND FUNCTIONING OF AUTOMATED SYSTEMS IN FORENSIC EXPERT ACTIVITY
}

\section{Popovich E. N.}

This article presents problems related to understanding, classification and implementation of the principles of organization and operation of automated systems in forensic expert activity. The basis of the classification is adoption of systems that can be used in activities of forensic science institutions. Depending on the destination, information systems differentiate into the following types: documentary and factographic. Forensic science institutions mainly use factographic information systems in their activities. Each information system, depending on the purpose of creation, can be constructed according to certain principles. We have provided a detailed analysis of such fundamental principles of automated system activity, namely: principle of legality; principle of information selection; principle of using hardware and software modules; principle of the possibility of step-bystep creating an information system; principle of simplicity and flexibility in terms of specific requirements of concrete information system application; principle of system acceptance for user of the "human - machine" dialogue; principle of distribution of information support; principle of task originality; principle of structural organization; principle of system approach; principle of combining the preparation of primary and machine documents; the principle of consistency of bandwidth of individual parts of a system; principle of data bank security; principle of using a professional language, etc. Author's definition of legality in forensic expert activity is presented that is understood as a complex social and legal phenomenon which main criterion is the legality category consisting of a set of subjective rights reflected and fixed in current legislation, formed as a result of objective social development.

Keywords: principles of work, information systems, forensic expert researches, informational support, expert systems.

DOI: https://doi.org/10.32353/khrife.2018.28

УДК 343.982 .323

B. B. Tonчій, директор Навчально-наукового інституту права Університету державної фіскальної служби України, доктор юридичних наук, професор, заслужений юрист України

E-mail: tv1959@ukr.n

\section{АКТУАЛЬНІСТЬ СУДОВОЇ МОЛЕКУЛЯРНО-ГЕНЕТИЧНОЇ ЕКСПЕРТИЗИ ТА ПРОБЛЕМНІ ПИТАННЯ ЩОДО ЇЇ ПРОВЕДЕННЯ}

Розглянуто особливості та сучасні можливості використання молекулярно-генетичних методів дослідження під час кримінального провадження. Проаналізовано проблеми проведення судової молекулярно-генетичної експертизи та визначено иляхи їх вирішення, а також перспективи використання ДНК-аналізу в Україні.

Ключові слова: ДНК-аналіз, молекулярно-генетична експертиза, ідентифікація, генотипоскопія, кримінальне провадження.

(C) Топчій В. В., 2018 
Значної популярності серед досягнень науки наприкінці XX i на початку XXI ст. у світовій судовій медицині набув метод генотипоскопії в біологічній експертизі, або ДНК-аналіз, завдяки якому створено сучасні способи ідентифікації особи. Це найбільш ефективний метод дослідження слідів біологічного походження, який використовується в експертно-криміналістичних установах України при проведенні судово-медичних експертиз у кримінальному провадженні.

Загальним проблемам використання спеціальних знань і зокрема ДНКаналізу під час розслідування злочинів присвячені праці А. І. Вінберга, В. Г. Гончаренка, Г. І. Грамовича, Ю. М. Грошевого, А. Я. Дубинського, В. С. Зеленецького, А. В. Іщенка, Н. І. Клименко, І. М. Козаченка, В. О. Коновалової, О. Н. Колесніченка, Г. В. Кривди, М. В. Костицького, Є. Д. Лук'янчикова, О. В. Матарикіної, Г. В. Мудрецької, С. В. Петричука, I. Я. Фрідмана та ін. У розробках цих учених розглянуто важливі положення для проведеного дослідження постановленої проблеми.

Мета статті - дослідження питань щодо використання ДНК-аналізу, конкретизації його місця й ролі в системі засобів і прийомів розслідування злочинів, розроблення пропозицій подальшого вдосконалення нормативноправової бази в цій сфері.

Вимоги сучасності ставлять перед суб'єктами, які здійснюють кримінальне провадження, завдання щодо впровадження в систему доказів усе більш широких можливостей судових експертиз. Також помітно зростає роль речових доказів, висновків експертів як найважливіших об'єктивних джерел створення надійної доказової бази в розслідуванні злочинів. Наразі йдеться про ідентифікацію осіб при розслідуванні тяжких злочинів, зокрема вбивств, у тому числі на замовлення, нанесення тяжких тілесних ушкоджень, злочинів, пов'язаних із викраденням людей.

На сьогодні одним із найефективніших методів дослідження слідів біологічного походження, що використовуються в експертно-криміналістичних установах, є метод ДНК-аналізу, який дозволяє провести ідентифікацію людини майже зі стовідсотковою точністю при порівнянні даних ДНК. Об'єктом молекулярно-генетичного дослідження може бути ядерна ДНК, отримана з крові, виділень (сперми, слини, букального та іншого епітелію тощо), волосся (за наявності в ньому волосяної луковиці), а також із частин органів і тканин організму людини ${ }^{1}$.

Уперше про можливість дослідження такого матеріалу повідомили англійські вчені в 1985 р. Відтоді цей напрям у судовій медицині почав стрімко розвиватися й отримав назву «генотипоскопія», «ДНК-аналіз», «молекулярно-генетична експертиза», «судово-медичний ДНК-аналіз» та ін. ДНК-типування міцно увійшло в експертну діяльність судово-медичних служб значної кількості розвинутих країн світу: Великобританії, Франції,

${ }^{1}$ Петричук C. B. Особливості призначення та проведення молекулярно-генетичних експертиз. Сучасні криміналістичні експертизи в розслідуванні злочинів : матеріали «круглого столу» (Київ, 25 лютого 2015 р.). Київ : Нац. акад. внутр. справ, 2015. C. 46. 
Німеччини, Австрії, Італії, Іспанії, США, Швейцарії, Японії та ін. В Україні цей метод ідентифікації особи в Експертній службі МВС почав працювати 3 90-х pp. XX ст. в Державному науково-дослідному експертно-криміналістичному центрі ${ }^{1}$.

Молекулярно-генетична ідентифікація є новим науковим знанням, що відкриває перспективи вирішення ідентифікаційних завдань у кримінальному процесі та розвитку доказової бази й має низку переваг перед традиційними серологічними методами дослідження біологічних слідів людини, a came:

1) структура молекули ДНК є більш стійкою до дії фізико-хімічних чинників оточуючого середовища порівняно з білками та іншими сполуками;

2) наявність у ДНК повної інформації про генотип людини в кожній клітині організму, яка містить ядро;

3) методики дослідження таких мікрослідів (клітини в слині, спермі, луковиці волосся з піхвовою оболонкою тощо) дозволяють здійснити ідентифікацію людини з точністю до 99,9%;

4) можливість диференціації змішаних слідів і факту змішування біологічного матеріалу декількох осіб.

Аналізуючи ці положення, можна стверджувати про високий ступінь імовірності висновків експертів щодо належності слідів певній особі.

Сучасні досягнення судово-медичної молекулярно-генетичної експертизи дозволяють отримувати інформацію про конкретну особу за допомогою найрізноманітніших слідів біологічного походження, особливо під час учинення тяжких злочинів проти життя й здоров'я людини, які зазвичай виявляються на місці події та належать організму людини. Значна перевага цього методу при розслідуванні кримінальних злочинів полягає саме в надійному виключенні з кола підозрюваних осіб, які не причетні до вчинення злочину, в ідентифікації осіб, які вчинили злочин, із високим ступенем імовірності.

Використання молекулярно-генетичної ідентифікації особи за біологічними слідами дозволяє вирішити декілька завдань.

По-перше, установити належність біологічних слідів (кров, сперма, слина, волосся), виявлених на місці вчинення злочину, особі, яка підозрюється в його вчиненні.

По-друге, установити, що біологічні сліди, вилучені з місць нерозкритих злочинів, належать одній особі. Це дозволяє висунути версію про вчинення серії злочинів однією особою, об’єднати наявну інформацію про розрізнені

Матарикіна O. В. Актуальність молекулярно-генетичної експертизи на етапі сучасного розвитку криміналістики. Сучасні тендениії розвитку криміналістики та кримінального процесу : тези доп. міжнар. наук.-практ. конф. до 100-річчя від дня народження проф. М. В. Салтевського, Харків, 8 листоп. 2017 р. Харків, 2017. С. 126. URL: https:/www.naiau.kiev.ua/files/naukova-diyalnist/naukovi zaxodi/zbirnuki/2015/ zb-krum-ekspert.pdf. 
злочини та під іншим кутом підійти до їі оцінювання та складання психологічного профілю злочинця ${ }^{1}$.

По-третє, здійснити зіставлення біологічних слідів, вилучених 3 місця злочину, з інформаційними базами ДНК, які формуються правоохоронними органами.

По-четверте, диференціація ДНК у змішаних слідах біологічного походження дає можливість установити кількість осіб, яким належить біологічна речовина.

По-п’яте, установити, чи є родинні зв'язки між особами у випадках дітовбивства, крадіжки чи підміни дітей тощо.

Отже, дослідження біоматеріалу з метою ідентифікації особи проводяться в таких випадках:

1) установлення належності біоматеріалу конкретній особі або виключення такої належності;

2) установлення статевої належності біологічних слідів і об'єктів;

3) настання вагітності після згвалтування з метою встановлення, що вагітність настала від підозрюваного та що він $є$ генетичним батьком дитини, або виключення цього;

4) дітовбивств (у тому числі новонароджених), викрадення дітей, підміни їх у пологовому будинку для встановлення, чи є особи, що проходять у справі, батьками дитини;

5) установлення, чи є рештки або частини трупа рештками однієї людини та чиїми саме за дослідженням зразків близьких родичів;

6) виявлення зв'язку між різними злочинами - установлення, що сліди біоматеріалу, які виявлені на місцях різних злочинів, залишені однією й тією самою особою;

7) порівняння генетичного профілю біологічного об’єкта з генетичними даними, які зберігаються в комп'ютерній базі даних, і за співпадіння - зорієнтувати слідство на пошук певної особи тощо 2 .

Попри стрімкий розвиток ДНК-аналізу та його актуальність у сучасній судовій медицині, виникає питання про його недоліки, проблеми проведення та шляхи їх вирішення.

По-перше, це відсутність чіткого законодавчого регулювання. Відповідно до закону ДНК-аналіз - лише один із видів доказів, а згідно 3 ч. 2 ст. 94 Кримінального процесуального кодексу України жоден доказ не має наперед установленої сили. Тому судді не розцінюють результати судової молекулярно-генетичної експертизи як істину останньої інстанції: вони

\footnotetext{
1 Лук'янчиков С. Д. Використання ДНК-аналізу у кримінальному провадженні. Сучасні криміналістичні експертизи в розслідуванні злочинів : матеріали «круглого столу» (м. Київ, 25 лютого 2015 р.). Київ : Нац. акад. внутр. справ, 2015. C. 40. URL: https://www.naiau.kiev.ua/files/naukova-diyalnist/naukovi zaxodi/zbirnuki/2015/zb-krumekspert.pdf.

2 Мудрецька Г. В., Цикова О. В. Проблеми використання даних ДНК аналізу під час розслідування злочинів. Наук. вісн. Ужгород. нац. ун-ту. Сер.: Право. 2014. Вип. 26. С. 248. URL: http://nbuv.gov.ua/UJRN/nvuzhpr_2014_26_65.
} 
можуть урахувати цей факт при винесенні судового рішення, а можуть і відкинути його.

У багатьох розвинутих країнах Заходу (США, Франції, Німеччині та ін.) уже прийнято законодавчу базу, яка не дозволяє проводити судочинство в кримінальних і цивільних справах, пов'язаних з ідентифікацією особи, без проведення молекулярно-генетичного аналізу. Наприклад, за даними американської наукової юридичної літератури, протягом останніх декількох років завдяки аналізу ДНК було отримано докази, що дали підстави для звільнення 72 ув'язнених; 8 осіб уникнули смертного вироку; а 318 тис. затриманих за підозрою у згвалтуванні чи вбивстві зі згвалтуванням - звільнено 27 осіб унаслідок розбіжностей їх генетичного коду 3 кодом справжнього злочинця ${ }^{1}$.

Унесення змін і доповнень у Кримінальний процесуальний кодекс України дозволило б розробити на відомчому рівні всіх необхідних положень 3 метою успішного використання ДНК-аналізу в практиці боротьби зі злочинністю.

По-друге, проблема інтерпретації результатів молекулярно-генетичного дослідження, яка пов’язана 3 недостатньою кількістю даних. Таким чином, експерт змушений включати в дослідження більшу кількість праймерів, для того щоб підвищувати ймовірність доказів і виключити випадковий збіг генотипів ${ }^{2}$.

Для вирішення цієї проблеми ефективним було б прийняття рішення щодо створення Національної бази даних генетичних ознак людини. Поки що створення бази стримується через відсутність чіткого законодавчого врегулювання цього питання та недостатню кількість і потужність наявних ДНК-лабораторій.

У розвинутих країнах ефективність використання таких баз для пошукових і слідчих цілей підтверджено досвідом їх використання. Наприклад, в Англії накопичено сотні тисяч генетичних профілів, які активно використовуються при розслідуванні злочинів. Для порівняння, в Одеському обласному бюро судово-медичних експертиз зібрано лише декілька сотень генотипів ДНК.

Одним із найважливіших аспектів є можливість використання криміналістичних обліків генетичних ознак людини з інформаційно-пошуковими автоматизованими системами ${ }^{3}$. Такі автоматизовані обліки зберігають і накопичують дані, отримані в процесі дослідження, з метою їх подальшої перевірки шляхом порівняння з даними, що вже внесені в базу. Використання даних бази ДНК дає можливість установити зв'язок між кількома злочинами, учиненими однією особою. За наявності бази даних про генетичні ознаки об'єктів, вилучених із місць нерозкритих злочинів, можна порівняти пошукову інформацію про кількість злочинів, які є серійними, і встановити зв'язок між ними.

1 Кривда Г.Ф., Лавренюк В. І. Оцінка судом судово-медичних молекулярногенетичних експертиз та необхідність їх законодавчої регламентації. Правова держава. 2003. № 6. С. 194.

2 Там само. C. 195.

3 Матарикіна О. В. Зазнач. твір. С. 127. 
По-трете, мають місце типові недоліки при вилученні біологічних слідів і призначенні експертиз. При вилученні біологічних слідів до таких належать: неправильне пакування вологих об'єктів; використання як упаковок поліетиленових пакетів, мішків та ін.; забруднення об'єктів, які містять біологічні сліди, тощо, а при призначенні експертиз: тривалий проміжок часу між вилученням матеріалів і проведенням експертизи; направлення на експертизу стріляних гільз (температура під час пострілу досягає $600{ }^{\circ} \mathrm{C}$ та знищує біологічні сліди), змивів речовини бурого кольору з-під трупа тощо.

Слід звернути увагу, що наявність позитивних результатів ідентифікації слідів біологічного походження залежить від успішних практичних дій працівників правоохоронних органів та експертів судово-медичних лабораторій. Тому треба розробити та закріпити на законодавчому рівні певні стандарти, які будуть містити положення про правила вилучення біологічних слідів і порядок проведення молекулярно-генетичної експертизи. Зокрема, слід заборонити всім учасникам огляду (обшуку), крім спеціалістів, брати в руки або торкатися предметів, на яких містяться сліди біологічного походження. Крім того, необхідно зобов'язати призначати експертизу на 1-3 день після вилучення об'єктів.

По-четверте, терміни виконання молекулярно-генетичних експертиз значно перевищують строки досудового розслідування, відкладаються на тривалий проміжок часу за черговістю їх виконання та у зв'язку зі значним навантаженням експертів, що перешкоджає швидкому виконанню завдань кримінального провадження, повному й неупередженому дослідженню його обставин, забезпеченню прийняття обгрунтованих рішень у розумні строки.

На нашу думку, головною проблемою є недостатня кількість ДНКлабораторій в експертних підрозділах МВС, МO3 і їх цілковита відсутність у інших правоохоронних органах. Можливості існуючих лабораторій не задовольняють потреби органів досудового розслідування в розкритті та розслідуванні тяжких і резонансних злочинів. Тому вирішувати цю проблему потрібно шляхом розширення мережі лабораторій, які проводитимуть молекулярно-генетичну експертизу.

По-п’яте, на сьогодні існують важливі питання, пов'язані з реєстрацією генетичних даних. Можливість зберігання й використання генетичної інформації розглядається в контексті охорони прав особи. У зв'язку з цим масштабне ДНК-типування нині не проводиться.

Підсумовуючи наведе, доходимо таких висновків:

- на сучасному етапі розвитку судової молекулярно-генетичної експертизи існують суттєві прогалини в законодавстві, які вирішуються шляхом прийняття відповідних нормативно-правових актів і вдосконалення чинних;

- ефективним методом для розвитку ДНК-аналізу є створення відповідних баз генетичних ознак особи. Проте законодавче закріплення цього процесу повинно відбуватися в контексті поваги та охорони прав особи;

- наразі терміни виконання молекулярно-генетичних експертиз значно перевищують строки досудового розслідування. Ця проблема може бути вирішена шляхом розширення мережі лабораторій, які проводитимуть таку експертизу. 
Попри наявність проблем, можна стверджувати, що ДНК-аналіз є найбільш ефективним і надійним з усіх відомих у світі методів ідентифікації особи на сучасному етапі. Наразі експертний молекулярно-генетичний аналіз розвивається не тільки як розділ молекулярно-генетичних досліджень, але і як повноцінний елемент криміналістичного знання, яке спрямоване на розслідування й розкриття злочинів. Тому впровадження молекулярно-генетичних методів дослідження в практику роботи правоохоронних органів в Україні значно підвищить ефективність розслідування багатьох тяжких злочинів проти особи.

\section{АКТУАЛЬНОСТЬ СУДЕБНОЙ МОЛЕКУЛЯРНО-ГЕНЕТИЧЕСКОЙ ЭКСПЕРТИЗЫ И ПРОБЛЕМНЫЕ ВОПРОСЫ, КАСАЮЩИЕСЯ ЕЕ ПРОВЕДЕНИЯ}

\section{Топчий В. В.}

Современные достижения судебно-медицинской молекулярно-генетической экспертизы позволяют получать информацию о конкретном лице с помощьью разнообразнейших следов биологического происхождения, особенно во время совершения тяжких преступлений против жизни и здоровья человека, которые по обыкновению оказываются на месте события и принадлежат организму человека. Значительное преимущество этого метода при расследовании уголовных преступлений состочт именно в надежном исключении из круга подозреваемых лиц, не причастных к совершению преступления, в идентификации лиц, которые совершили преступление с высокой степенью вероятности. На современном этапе развития судебной молекулярно-генетической экспертизы имеются существенные пробель в законодательстве, которые решаются путем принятия соответствующих нормативно-правовых актов и усовершенствования действующих. Эффективным методом для развития ДНК-анализа является создание соответствуюших баз генетических признаков человека. Однако законодательное закрепление этого процесса должно происходить в контексте уважения и охраны прав личности. Сейчас сроки выполнения молекулярно-генетических экспертиз значительно превышают сроки досудебного расследования. Эта проблема может быть решена путем расширения сети лабораторий, которые будут проводить такую экспертизу. Вопреки наличию небольшого количества проблем, можно утверждать, что ДНК-анализ является наиболее эффективным и надежным из всех известных в мире методов идентификации личности на современном этапе. Сейчас экспертный молекулярно-генетический анализ развивается не только как раздел молекулярно-генетических исследований, но и как полноценный элемент криминалистического знания, которое направлено на расследование и раскрытие преступлений. Поэтому внедрение молекулярно-генетических методов исследования в практику работы правоохранительных органов в Украине значительно повысит эффективность расследования многих тяжких преступлений против личности.

Ключевые слова: ДНК-анализ, молекулярно-генетическая экспертиза, идентификация, генотипоскопия, уголовное производство. 


\title{
TOPICALITY OF FORENSIC MOLECULAR GENETIC EXAMINATION AND ISSUES REGARDING ITS PERFORMING
}

\author{
Topchiy $V . V$.
}

Modern progress in forensic molecular genetic examination allow to obtain information about a particular person using traces variety of biological origin especially while committing grave crimes against human life and health, that are usually found at the scene and belong to a human body. A significant advantage of this method under crime investigation is precisely the safe exclusion of suspected persons not involved in the commission of a crime, in identifying those who committed a crime with a high probability level. At the present stage of forensic molecular genetic examination development there are significant gaps in legislation that are solved by adopting relevant normative and legal acts and improving existing ones. Effective method for of DNA analysis development is the creation of appropriate bases of genetic features of a person. However, the legislative consolidation of this process should take place in the context of respecting and protecting personal rights. However, terms of performing molecular genetic examination significantly exceed the terms of pre-trial investigation. This problem can be solved by expanding network of laboratories that perform such examination. Despite presence of a small number of problems, it is possible to affirm that DNA analysis is the most effective and reliable of all known methods of person identification at the present stage. At present, expert molecular genetic analysis develops not only as a section of molecular genetic research but also as a complete element of criminalistic knowledge that is aimed at investigating and disclosing crimes. Therefore, implementation of molecular genetic research methods into the practice of law enforcement agencies in Ukraine will significantly increase investigation effectiveness of many serious crimes against person.

Keywords: DNA analysis, molecular genetic examination, identification, genotype profiling, criminal proceedings.

DOI: https://doi.org/10.32353/khrife.2018.29

УДК 343.98

A. А. Русецький, провідний науковий співробітник Харківського НДІСЕ, кандидат юридичних наук, доцент

E-mail: hniise@gov.ua

\section{МІСЦЕ СУДОВИХ ЕКСПЕРТИЗ У СИСТЕМІ ПРОТИДІЇ КІБЕРЗАГРОЗАМ У СФЕРІ ІНФОРМАЦЙНОЇ БЕЗПЕКИ УКРАЇНИ}

Здійснено аналіз наукових думок щзодо змісту протидії кіберзагрозам у сфері інформаційної безпеки України, визначено місие й функиії судової експертизи в иій діяльності. Уточнено зміст експертної профілактики та з'ясовано функиї-завдання, щзо вирішуються під час виявлення злочинів із втручання в роботу інформаційно-телекомунікаційних систем. Надано рекомендації щзодо напрямів здійснення наукових досліджень для формування теоретичного підгрунтя використання судових експертиз у протидї кіберзагрозам.

(C) Русецький А. А., 2018 